\author{
Paulina Charko-Klekot \\ Uniwersytet Śląski w Katowicach \\ iD \\ ORCID https://orcid.org/0000-0002-1265-6934
}

\title{
DRAMATOPISARKI W NATARCIU - FEMINISTYCZNY CHARAKTER NAJNOWSZEJ DRAMATURGII ROSYJSKOJĘZYCZNEJ
}

\author{
WOMEN PLAYWRIGHTS ON THE ATTACK - THE FEMINIST \\ CHARACTER OF CONTEMPORARY RUSSIAN-SPEAKING DRAMATURGY
}

This article enumerates the most salient features of works by the youngest contemporary Russian-speaking playwrights of Eastern Europe, including Irina Vaskovska, Asya Voloshyna, Natalya Blok, Olga Shilyayeva and Darya Slyusarenko. Conducted from a feminist perspective, the study discusses various ways in which the plays contradict a male-centric vision of the world. Their authors undertake the (re-)definition of the concept of femininity by proposing new perspectives on seemingly well-known topics such as motherhood, family relationships, sexuality, and corporeality. The protagonists of the plays presented in the text oppose the social and moral norms that limit them, make attempts to go beyond those cliches, and fight for the opportunity to be themselves.

Keywords: the latest Russian-speaking dramaturgy, feminism, femininity, involved drama

ЖЕНЩИНЫ-ДРАМАТУРГИ В НАСТУПЛЕНИИ - ФЕМИНИСТСКИЙ
ХАРАКТЕР НОВЕЙШЕЙ РУССКОЯЗЫЧНОЙ ДРАМАТУРГИИ

В статье приводятся характеристики творчества самых молодых русскоговорящих драматургов Восточной Европы, в частности, Ирины 
Васьковской, Аси Волошиной, Натальи Блок, Ольги Шиляевой и Дарьи Слюсаренко. Анализу, с феминистской точки зрения, подвергались пьесы, которые по-разному противостоят мизогиническому видению мира. Их авторы пытаются переопределить понятие женственности: драматурги предлагают новый взгляд на, казалось бы, знакомые темы, такие как материнство, семейные отношения, сексуальность или телесность. Героини представленных в статье пьес выступают против ограничивающих их социальных и нравственных норм, предпринимают попытки выйти за рамки устоявшихся схем и вступают в борьбу за возможность быть собой. Ключевые слова: новейшая русскоязычная драматургия, феминизм, женственность, социально ангажированная драма

Jedną z piękniejszych cech literatury jest ogrom możliwości jej odczytań. Ten sam tekst może być inaczej odebrany w zależności od wieku, płci, wykształcenia, wychowania czy doświadczeń czytelnika. Jeśli zatem interpretacja przeczytanych treści jest częściowo uwarunkowana osobą czytającego, to na pytanie „czy ma znaczenie, kto mówi?” właściwą wydaje się odpowiedź Joanny Bednarek — „oczywiście, że ma”. Szczególnie dyskurs feministyczny pozostaje wyczulony na figurę autora i mimo pewnych różnic w podejściu ${ }^{2}$ postuluje uwzględnianie warunków powstawania tekstu podczas analizy. „Usytuowanie pisarza, jego etniczność, narodowość i płeć są tutaj częścią maszyny tekstualnej i mają wpływ na jej postać"3 - zauważa Bednarek, proponując dalej, by pisarstwo kobiet traktować jako literaturę mniejszą w rozumieniu Gilles’a Deleuze’a i Féliksa Guattariego, czyli jako twórczość, którą mniejszość pisze w języku dominującym, przez co ma zdolność destabilizowania

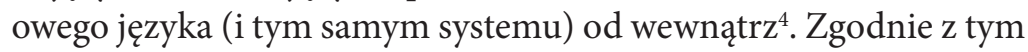
podejściem każdy kobiecy głos w literaturze zaburza męską hegemonię, rozszerza perspektywę postrzegania i umożliwia wypowie-

\footnotetext{
${ }^{1}$ J. Bednarek, Linie kobiecości. Jak różnica płciowa przekształciła literaturę i filozofię, Narodowe Centrum Kultury-Fundacja na rzecz Myślenia im. Barbary Skargi, Warszawa 2015, s. 14.

${ }^{2}$ Oddzielenie tekstu od jego autora/autorki postulowała np. Hélène Cixous, której koncepcja była bliska Derridiańskiej myśli o tym, że płeć może mieć sam tekst, a nie tylko jego autor. Zob. tamże, s. 14-19.

${ }^{3}$ Tamże, s. 46.

${ }^{4}$ Tamże, s. 42.
} 
dzenie tego, co dotąd było niemożliwe. W tym znaczeniu nabiera on również charakteru politycznego: „Dobra literatura, podobnie jak dobra polityka, wprowadza do wspólnego świata coś, czego wcześniej tam nie było; obie przemieszczają i poszerzają horyzont tego, co wyobrażalne"s.

Celem niniejszego artykułu jest próba charakterystyki najmłodszego pokolenia rosyjskojęzycznych ${ }^{6}$ dramatopisarek w kontekście literatury zaangażowanej feministycznie. Jako najmłodszą generację traktuję autorki debiutujące około roku 2010 - w tym czasie, jak zauważa krytyk teatralny Paweł Rudniew, kobiety zaczynają dominować w dramaturgii ${ }^{7}$. Ponadto dekada wydaje się wystarczającym okresem pozwalającym na wyodrębnienie pewnych ogólnych tendencji.

Warto podkreślić, że ten mocno wybrzmiewający współcześnie głos kobiecy nie pojawił się znikąd, ale ma długą tradycję w literaturze rosyjskiej. Sui generis pierwszą falę dramaturgii pisanej przez płeć piękną można wyodrębnić na przełomie XIX i XX wieku - Zinaida Gippius, Teffi, Lidia Zinowjewa-Annibal, Aleksandra Mire czy Anna Mar, choć znane głównie ze swojej twórczości poetyckiej lub prozatorskiej, zajmowały się również pisaniem dla

\footnotetext{
${ }^{5}$ Tamże, s. 49.

${ }^{6}$ Mam tu na myśli autorki z Rosji, Ukrainy i Białorusi, które piszą i publikują po rosyjsku, biorą udział w rosyjskich konkursach i festiwalach dramaturgicznych (takich jak „Lubimowka”), a ich twórczość jest obecna w życiu teatralnym i kulturalnym Rosji oraz postrzegana jako część „nowego dramatu” rosyjskiego.

${ }^{7}$ П. Руднев, Драма памяти. Очерки истории российской драматургии. 1950-2010-е, Новое литературное обозрение, Москва 2018, s. 442. Badania socjologiczne przeprowadzone w latach 2004-2008 przez Swietłanę Koczerinę (koordynatorkę konkursu dramaturgicznego „Премьера.txt”) i socjolożkę Julię Miekajewą wśród uczestników konkursu „Премьера.txt” (zgromadzono wywiady socjologiczne z 1018 osobami) wykazały, że jeśli chodzi o liczbę nadsyłanych sztuk, to rok 2006 był przełomem - spośród zgłoszonych utworów ponad $50 \%$ stanowiły teksty autorstwa kobiet. Ze względu na konieczność ograniczenia analizowanego materiału na potrzeby niniejszego artykułu jako punkt odniesienia dla badań nad feministycznym charakterem współczesnej dramaturgii uznaję rok 2010. Zob. С.В. Кочерина, Ю.Ю. Мекаева, Современная драматургия: состояние, тендениии, перспективы. Социологическое исследование, Академика, Москва 2008, s. 18.
} 
teatrów ${ }^{8}$. Sprzyjający feministycznym tendencjom modernizm dawał nadzieję na rozkwit kobiecego pisarstwa, jednak czasy Związku Radzieckiego, począwszy od końca lat 20. aż do lat 70., spowodowały ponowne zamilknięcie kobiet w literaturze. Przełom przyniosła epoka zastoju, kiedy to autorki, takie jak Ludmiła Pietruszewska, Ałła Sokołowa, Ludmiła Razumowska czy Nadieżda Ptuszkina, podjęły dialog z męskocentryczną wizją świata ${ }^{9}$. O zdecydowanym rozkwicie literatury i dramaturgii kobiecej można mówić wraz z nastaniem epoki pieriestrojki, która przyniosła nie tylko wzrost zainteresowania teoriami feministycznymi, ale także imponującą liczbę pisarek, których twórczość została doceniona przez krytykę i publiczność. Od lat 90. XX wieku w repertuarach teatrów na stałe goszczą sztuki takich dramatopisarek jak: Nina Sadur, Maria Arbatowa, Jelena Gremina, Ksenia Draguńska, Jelena Isajewa, Olga Muchina, Jekaterina Narszi czy Natalia Worożbyt.

Rozpatrywanie literatury w kontekście jej feministycznego charakteru może być kłopotliwe - już samo określenie fe mi nistyczny/feministyczna przysparza problemów: po pierwsze, będąc dość szerokim, na wstępie wymaga doprecyzowania, a po drugie, nadal wzbudza niechęć, nawet wśród samych autorek. Obecne ro-

${ }^{8}$ Obszerny esej na temat dramaturgii kobiecej z początku XX wieku autorstwa Marii Michajłowej został opublikowany w antologii Женская драматургия Серебряного века. Zob. М. Михайлова, „Бабы с пьесами...” в эпоху modern (предисловие), w: tejże (oprac.), Женская драматургия Серебряного века, Гиперион, Санкт-Петербург 2009, s. 5-64. Z polskich badań nad żeńską dramaturgią tamtego okresu można wyróżnić np. monografię Haliny Mazurek. Zob. H. Mazurek, Róża i Płaszcz. Teatr Mariny Cwietajewej, WW Oficyna Wydawnicza, Katowice 2009.

${ }^{9}$ Szczegółową charakterystykę twórczości kobiet w epoce zastoju i punkty sporne $\mathrm{w}$ dialogu $\mathrm{z}$ dramaturgami zob. w pracach Tatiany Karpowej, np. Т. Карпова, Гендерный фактор в драматургическом тексте, „Вестник ВГУ. Серия: Филология. Журналистика" 2016, nr 3, s. 46-48; tejże, Женская драматургия периода застоя в аспекте гендерного диалога, „Исторические, философские, политические и юридические науки, культурология и искусствоведение. Вопросы теории и практики" 2016, nr 5 (67), s. 99-103; tejże, К вопросу о динамике творческой активности женщин-драматургов: причины и факторы, „Исторические, философские, политические и юридические науки, культурология и искусствоведение. Вопросы теории и практики” 2014, nr 5 (43), s. 97-101. 
zumienie feminizmu ${ }^{10}$ zdecydowanie wykracza poza walkę o prawa kobiet. Podejście feministyczne interpretuje się współcześnie jako takie, które oddaje głos grupom wykluczonym — zarówno kobietom, jak i wszelkiego rodzaju mniejszościom (seksualnym, narodowym itd.), osobom niepełnosprawnym, dzieciom, nastolatkom czy osobom starszym. Włączanie do przestrzeni widzialności tych wszystkich, których potrzeby w dotychczasowych dyskursach były (lub są) marginalizowane, jest działaniem o charakterze politycznym przy rozumieniu polityczności jako możliwości ingerowania w otaczającą rzeczywistość i skłaniania jej „do zmiany układu tego, co uważamy za możliwe do pomyślenia, powiedzenia i zrobienia"11. Połączenie perspektywy feministycznej z twórczością społecznie zaangażowaną wydaje się obecnie najczęściej uwzględnianym podejściem nie tylko przez krytykę teatralną, ale i autorów. Dziennikarka i teatrolożka Kamila Mamadnazarbekowa konstatuje:

Феминизм - это гуманизм. Он всегда идет рука об руку с борьбой за другие базовые гражданские ценности и права. История движения за равные права женщин, детей, животных, национальных и сексуальных меньшинств, чернорабочих и обслуживающего персонала - это всегда одна и та же история борьбы за социальную справедливость ${ }^{12}$.

${ }^{10}$ Już od dawna mówi się częściej o feminizmach niż jednym feminizmie. W zależności od przyjętych kryteriów badacze wyróżniają feminizm akademicki, socjopolityczny, liberalny, lewicowy itd. Zob. M.P. Markowski, Feminizm, w: A. Burzyńska, tegoż, Teorie literatury XX wieku, Znak, Kraków 2006, s. 391-402. Często również podkreśla się opozycyjny charakter nurtów w feminizmie: „Мало того, что феминизмов много и часто они находятся в конфронтации друг с другом по многим вопросам (а значит, всякий раз произнося 'феминизм', мы вынуждены уточнять, о каком из них говорим), но и потому, что здесь нет и не может быть единого классификационного принципа". Zob. М. Исраилова, А. Дунаева, Четыре версии феминистского искусства из Петербурга, „Театр” 2019, nr 38, http://oteatre.info/chetyreversii-feministskogo-iskusstva-iz-peterburga/ (24.08.2020).

${ }^{11}$ A. Wójcik, Geopolityka namiętności. Rozmowa z Jacquesem [!] Rancièrem, https://publica.pl/teksty/geopolityka-namietnosci-rozmowa-z-jacquesemrancierem-51329.html (24.08.2020).

${ }^{12}$ К. Мамадназарбекова, Новый феминизм по-франиузски: за вашу и нашу свободу, „Театр” 2019, nr 28, http://oteatre.info/novyj-feminizm-po-frantsuzski/ (24.08.2020). 
O tym, że również same autorki chętniej określają własną twórczość bardziej jako polityczną czy zaangażowaną niż feministyczną, świadczy wypowiedź Ledy Gariny, reżyserki i kuratorki zainicjowanego w 2016 roku projektu „Żebra Ewy” / „Ребра Евы” (przez założycielki określanego jako „феминистский социальный, художественный и коммуникативный проект"13), która na pytanie o istotę feministycznego teatru odpowiedziała:

Я, честно говоря, не знаю, что такое феминистский театр, потому что считаю, что все виды искусства, в том числе и театр, должны быть политическими. То есть, если я нахожусь в реальности и рефлексирую все, что происходит вокруг, я не могу делать мое высказывание аполитичным. Лично я. Политическое - это попытка взаимодействовать с реальностью, отражать ее и влиять на нее, то есть попытка диалога с обществом на темы, которые актуальны здесь и сейчас. Это могут быть вопросы насилия в разных сферах ${ }^{14}$.

W tym kontekście feministyczny charakter dramaturgii wpisuje się w szerszą optykę „nowego dramatu” (ros. новая драма) rosyjskiego, dla którego zaangażowanie społeczne zawsze było ważne, a cechy, którymi krytyczki i badaczki opisują sztukę feministyczną, takie jak kontrowersyjność, dyskusyjność, łamanie tabu i podejmowanie prób zmian zastanego porządku świata ${ }^{15}, \mathrm{z}$ powodzeniem można przypisać również „nowemu dramatowi” w ogóle ${ }^{16}$. Być

${ }^{13}$ М. Исраилова, А. Дунаева, Четыре версии феминистского искусства...

14 Tamże. Rozumienie podejścia feministycznego jako sprzeciwiającego się uciskowi i podważającego obecny porządek świata zakłada możliwość nazywania feministycznymi sztuki pisane przez mężczyzn czy osoby niebinarne, w niniejszym tekście jednak takie utwory nie są analizowane ze względu na konieczność ograniczenia materiału badawczego.

${ }^{15}$ Natalia Zajcewa uznaje sztuki za feministyczne, jeśli spełniają następujące kryteria: „1) пьеса написана феминисткой или с феминистской позиции; 2) пьеса критикует патриархальный гендерный порядок; 3) пьеса предлагает проект нового мира - показывает пути уничтожения несправедливости": Zob. Н. Зайцева, Российская драматургия: настройка оптики, „Театр” 2019, nr 38, http://oteatre.info/nastrojka-optiki-o-feministskom-povorote-v-rossijskoj-dramaturgii/ (24.08.2020).

${ }^{16}$ Zob. К. Матвиенко, „Новая драма”: победа без триумфа, „Искусство кино" 2014, nr 3, http://kinoart.ru/archive/2014/03/novaya-drama-pobedabez-triumfa (24.08.2020). 
może właśnie ta bliskość tematyki jest jedną z przyczyn niechęci dramatopisarek do klasyfikacji ich twórczości ze względu na płeć. Innym, być może decydującym czynnikiem nieprzychylnego stosunku do określeń fe ministyczna i kobieca u autorek jest ciągle funkcjonujące społecznie przekonanie o drugorzędności literatury kobiecej. Nadal w kategoriach synonimicznych postrzegane są słowa człowiek i mężczyzna, a pod pojęciem kwestie ogólnoludzkie rozumie się zagadnienia wzniosłe, publiczne, związane z rozumem i kulturą, czyli bliższe tradycyjnie pojmowanemu męskiemu światu. Trafnie charakteryzuje ten problem Irina Waśkowska:

Мне не нравится „женское гетто” в драматургии: „ах, особый круг тем”, „ах, женские проблемы”, „ох, женское одиночество”, „женская психология”, „своя атмосфера”... Нет же никакого „мужского одиночества” и „мужских проблем”. Как будто „мужчина” - это равно „человек” (его проблемы - проблемы человека), а „женщина” равно „не вполне человек, но достойна уважения и внимания" ${ }^{17}$.

Kobieta, utożsamiana $\mathrm{z}$ naturą ze względu na swoją fizjologię i zdolność do przedłużania gatunku, została wpisana w procesach socjalizacji w kontekst domowy (karmienie, opieka, wychowywanie dzieci), a tym samym wykluczona $\mathrm{z}$ publicznego dyskursu - jedynego, jaki może być poważnie traktowany. To zepchnięcie kobiet $\mathrm{w}$ sferę prywatną i ujmowanie w kategoriach innego/ obcego przekłada się na postrzeganie ich twórczości jako gorszej, a przypisywane kobiecemu pisarstwu cechy są zwykle ambiwalentne (uczuciowość, sentymentalność, skłonność do romantyzmu) ${ }^{18}$ i wykorzystywane nie tylko jako komplement, ale i zarzut. Taki stereotypowy układ relacji między pisarstwem damskim i męskim powodował (a można odnieść wrażenie, że czyni to nadal) chęć ucieczki od płciowej identyfikacji swojej twórczości, postulując, jak kiedyś Jelena Isajewa, podział sztuk wyłącznie na złe lub dobre ${ }^{19}$

17 „Женский мир стал пристальным объектом исследования”. Участницы "Любимовки" о гендере и том, почему женщин в драматургии становится все больше, https://www.kommersant.ru/doc/4080460 (24.08.2020).

${ }^{18}$ Zob. С.В. Кочерина, Ю.Ю. Мекаева, Современная драматургия..., s. 18.

19 Tamże. Pragnienie bycia „neutralną genderowo”, jak określa taką postawę Tatiana Rowieńska, było charakterystyczne dla wielu autorek z końca XX 
lub, jak czyni to młoda dramatopisarka Natalia Błok, skupienie się na doświadczeniach człowieka jako jednostki:

Я считаю сексизмом делить авторов по половому признаку. Это непрофессионально и бесполезно. Личный опыт - бесценная вещь. Если у тебя есть месячные, то ты можешь писать про них достовернее того, у кого их не было ${ }^{20}$.

Stwierdzenie Błok, że osobiste przeżycia mają wpływ na powstający tekst, nieco wbrew intencji autorki, prowadzi do konstatacji, od której zaczyna się niniejszy artykuł, a mianowicie, że dla tekstu ważne jest, kto mówi, choćby dlatego właśnie, że może się podzielić indywidualnym doświadczeniem, które — jeśli jest inne niż dominujące - poszerza przestrzenie widzialnego. Jak zauważa inna początkująca autorka, Natalia Zajcewa, otwarcie mówiąca o feministycznym charakterze swojej twórczości, „[в] феминистской парадигме важен голос. Кто и с какой позиции высказывается? Какой важный акт содержится в этом высказывании? Разлом какой власти экспонируется через этот акт?"21. Sztuki napisane przez młode dramatopisarki rosyjskojęzyczne umożliwiają zapoznanie się z wielogłosem koncepcji dotyczących (re)definiowania istoty kobiecości.

Mimo znacząco lepszej niż przed laty pozycji płci żeńskiej w hierarchii społecznej, politycznej czy ekonomicznej nadal istnieją utarte schematy dotyczące bycia tzw. prawdziwą kobietą. Najnowsza dramaturgia, podobnie jak literatura i sztuka XXI wieku

- początku XXI wieku. Zob. T. Rowieńska, Historia prozy kobiecej w epoce transformacji, czyli „oczy szeroko zamknięte” rosyjskiego feminizmu, przeł. I. Kuźmina, w: E. Kraskowska (red.), Literatury słowiańskie po roku 1989. Nowe zjawiska, tendencje, perspektywy, t. 2: Feminizm, Kolor Plus, Warszawa 2005, s. 92. Przekonanie o niższości przymiotnika „kobiecy” w stosunku do oceny twórczości widać również w wypowiedziach badaczy - Walenty Piłat swój szkic o dramatopisarkach radzieckich zaczyna od zapewnienia, że choć pisze o „kobiecej” dramaturgii, to jest ona w dużym stopniu pisana „po męsku”. Zob. W. Piłat, Współczesna „kobieca” dramaturgia radziecka, "Język Rosyjski” 1989, nr 5, s. 259.

${ }^{20}$ „Женский мир стал пристальным объектом исследования”...

${ }^{21}$ Н. Зайцева, Российская драматургия: настройка оптики... 
w ogóle, podejmuje próby ucieczki od stereotypowych wyobrażeń o płci, kreśląc całe spektrum modeli kobiecości i męskości. Potrzeba przezwyciężenia dotychczasowych norm związanych z socjalizacją dziewcząt miesza się z wpojonym przekonaniem o słuszności tychże, co w twórczości dramaturgicznej przekłada się na konstruowanie bohaterek egzystencjalnie zagubionych, pozbawionych autorytetów oraz nieumiejących zakorzenić się w otaczającym świecie ${ }^{22}$. Teksty młodych dramatopisarek pokazują, że dziewczętom nadal przyswajane jest przekonanie, iż kobiecość polega na byciu bierną, wiodącą życie bez odstępstw od przyjętych w danej grupie społecznej zasad, atrakcyjną dla płci męskiej, eksponującą swoją seksualność, ale już nie fizjologię (menstruacja, ciąża, poród są tematami tabuizowanymi), opierającą poczucie własnej wartości na relacjach międzyludzkich, a nie osiągnięciach zawodowych. Konsekwencjami takiego wychowania są sytuacje, kiedy kobiety i młode dziewczyny, jak zauważają Judith M. Bardwick i Elizabeth Douvan, „szacują swoją wartość na podstawie reakcji innych; [...] mają dla siebie tyle uznania, ile okazują im ci, z którymi wchodzą w relacje emocjonalne" ${ }^{23}$. Z tego powodu priorytetem w życiu płci żeńskiej staje się wejście w związek, a następnie dbanie o to, by tę relację utrzymać. Jedną $\mathrm{z}$ autorek ukazujących te zależności jest Irina Waśkowska. W sztukach Lekcje miłości (Уроки сердия, 2011) ${ }^{24}$ czy Zakochane dziewczyny (Девушки в тюбви, 2015) poddaje re-

\footnotetext{
${ }^{22}$ Należy nadmienić, że poszukiwania tożsamościowe są charakterystyczne dla najnowszej dramaturgii w ogóle - Oleg Lipowiecki, reżyser teatralny i członek jury wielu konkursów dramaturgicznych, charakteryzując sztuki przysyłane w 2017 roku na konkurs „Lubimowka”, wśród najpopularniejszych tematów wymieniał wojnę i właśnie próby odnalezienia siebie we współczesnym świecie. Zob. Н. Фролова, „В огромном количестве пьес - война”, https://lubimovka. $\mathrm{ru} / \mathrm{blog} / 396-\mathrm{v}$-ogromnom-kolichestve-pes-vojna (24.08.2020).

${ }^{23}$ J.M. Bardwick, E. Douvan, Ambiwalencja: socjalizowanie kobiet, w: T. Hołówka (red.), Nikt nie rodzi się kobietą, przekł. tejże, Czytelnik, Warszawa 1982, s. 172.

${ }^{24}$ Sztuki zostały przetłumaczone na język polski przez Natalię Pietrulewicz i opublikowane w Antologii współczesnego dramatu rosyjskiego (oprócz wymienionych w tekście w skład antologii weszły jeszcze utwory Marzec i Ruska śmierć). Zob. A. Moskwin (red.), Antologia współczesnego dramatu rosyjskiego, t. 7: Szkoła uralska, SOWA, Warszawa 2017.
} 
fleksji postrzeganie kobiet w kategoriach braku — jako istot, które pełnię człowieczeństwa osiągają jedynie we wspólnocie z mężczyzną. W ten sposób nieobecność towarzysza życia staje się największym lękiem dręczącym postacie Waśkowskiej. Obsesyjna wręcz potrzeba bycia czyjąś żoną, narzeczoną, dziewczyną (przy czym status dwóch pierwszych jest zdecydowanie wyższy niż ostatniej) prowadzi bohaterki do patologicznego pojmowania miłości - ze strachu przed samotnością godzą się na przemoc, nieposzanowanie ich godności czy pogardę ze strony partnerów, a inne kobiety traktują jak potencjalne rywalki, nie dostrzegając siły drzemiącej w damskiej przyjaźni ${ }^{25}$.

Uzależnienie poczucia własnej wartości od opinii i oczekiwań innych bywa powodem frustracji, szczególnie gdy oczekiwania wobec zastanej rzeczywistości nie pokrywają się z wymaganiami otoczenia. Bohaterka sztuki Mama (Мама, 2016) ${ }^{26}$ Asi Wołoszyny czuje przygnębienie, gdy dokonuje rewizji swojego życia, zauważając, że więcej w nim cierpienia niż szczęścia, o którym marzyła dla niej matka. Traumatyczne sytuacje, których doświadczyła dziewczyna (np. gwałt) oraz poczucie bezsensu istnienia powodują, że Ola nie chce zakładać rodziny i ucieka od tradycyjnie pojmowanej kobiecości. Jednocześnie czuje ogromną presję, że żyjąc w taki sposób zawiodła nadzieje, które pokładali w niej najbliżsi, co skutkuje stopniowym pogrążaniem się $\mathrm{w}$ depresji $\mathrm{i}^{27}$.

Młode dziewczyny, wychowywane w przeświadczeniu o słuszności pasywnej i podporządkowanej postawy, często bywają niezdolne do wyrażenia swojego zdania i sprzeciwu wobec niewłaści-

${ }^{25}$ Należy jednak wspomnieć, że w sztuce Zakochane dziewczyny bohaterki dostrzegą bezsens bycia zależną od mężczyzn i w końcowych scenach uświadamiają sobie wagę własnej przyjaźni.

${ }^{26}$ Sztuka została przetłumaczona na język polski i opublikowana w czasopiśmie „Dialog”. Zob. A. Wołoszyna, Mama, przeł. K. Tyczko, „Dialog” 2018, nr 3, s. $160-185$.

${ }^{27}$ Analizę tej sztuki, a także kilku innych w kontekście wolności i możliwości decydowania o sobie przeprowadził Krzysztof Tyczko. Zob. K. Tyczko, Wolność i tragizm w twórczości Asi Wołoszyny, w: L. Mięsowska, P. Charko-Klekot, A. Tyka (red.), Maski wolności w dramacie i teatrze XX i XXI wieku, „Śląsk”, Katowice 2019, s. 295-313. 
wych zachowań ze strony innych. Socjalizowane do posłuszeństwa zostają jednocześnie pozbawione narzędzi ułatwiających szczerą komunikację, czemu wyraz daje Daria Sliusarenko w utworze Siedem razy osiem (Семью восемь, 2018). Jej bohaterka w przytłaczających i niekomfortowych dla niej sytuacjach najczęściej nie jest w stanie wydusić z siebie żadnego słowa: „[...] И я ничего тебе не рассказываю, совсем ничего, я только молчу и злюсь все время”; „Мы молчим. Мы молчим. Мы молчим. У меня в голове миллиарды слов”; „Мне больно. Мне кажется, у меня внутри сейчас все разорвется от крика"28. Nieumiejętność rozmowy prowadzi do zaburzeń relacji rodzinnych i partnerskich. Autorka pokazuje również, jak traumatyczne dla kształtowania dziecięcej oraz nastoletniej tożsamości jest przemocowe, autorytarne wychowanie bez miłości. Szczególnie przykry wydaje się fakt, że młoda bohaterka zostaje skrzywdzona przez najbliższe jej kobiety - matkę, która poświęciła się pracy, unikając obowiązków rodzicielskich, i babkę, która nie wspierała dorastającej wnuczki, ale pozbawiała ją poczucia godności, wpajając mizoginistyczne wartości i przekonanie o drugorzędności kobiet. Podobnie jak bohaterki Waśkowskiej, protagonistka sztuki Sliusarenko uzależniła poczucie afirmacji siebie od opinii otoczenia, co sprawiło, że postępowała często wbrew sobie, chcąc niejako zasłużyć na uznanie innych.

Rodzicielstwo jest przedmiotem refleksji nie tylko z perspektywy dziecka $-\mathrm{z}$ dużym zainteresowaniem młode autorki rozpatrują również macierzyństwo z punktu widzenia matki, szczególnie że jest ono istotnym elementem kształtowania żeńskiej podmiotowości: właściwie każda kobieta musi się zmierzyć z tym tematem i określić własny (pozytywny lub negatywny) stosunek do bycia matką. Dramatopisarki zwracają uwagę na wieloaspektowość tego zagadnienia i pokazują zarówno odpowiedzialne, świadome macierzyństwo, jak i to niechciane czy samotne. Przy czym zdecydowanie częściej portretowane są cienie niż blaski macierzyństwa, ponieważ, parafrazując Lwa Tołstoja, szczęście zwykle wygląda jednakowo, za to nieszczęścia mają różne oblicza. Macierzyństwo

${ }^{28}$ Д. Слюсаренко, Семью восемь, tekst dostępny na stronie festiwalu „Lubimowka”: https://lubimovka.ru/lyubimovka-god/622-short-list-2019 (24.08.2020). 
jawi się jako problematyczne m.in. dlatego, że zmusza do ponownego rozpatrywania kobiecości w kategoriach braku - prawdziwą kobieta jest wtedy, gdy ma potomstwo i męża. Nie zapominając, że w XXI wieku feminizm wywalczył już pewne zmiany w tym zakresie i status panny $z$ dzieckiem (lub bez niego) nie wywołuje takich kontrowersji jak kiedyś, to twórczość młodych dramatopisarek pokazuje, iż wciąż jest to temat budzący emocje. Jeden z ciekawszych przykładów potwierdzających tezę, że funkcja reprodukcyjna nadal jest priorytetową w myśleniu o kobietach, stanowi utwór Jekateriny Bronnikowej Glina (Глина, 2019). Dramatopisarka przygląda się problemowi bezpłodności i kwestii sztucznego zapłodnienia, zwracając uwagę na przeniesienie dyskusji o niepłodności ze sfery prywatnej do publicznej - głos w tej sprawie zabiera społeczeństwo, Cerkiew, przedstawiciele sektora usług komercyjnych, kwestia ta znajduje również odzwierciedlenie w przepisach prawa. Jedna $\mathrm{z}$ bohaterek dramatu Bronnikowej tak charakteryzuje zmagania kobiet z bezpłodnością:

Общество заставит тебя страдать. Добрые тетушки смогут пробить и выработать в тебе чувство неполноценности и униженности.

Государство сможет надиктовать твою никчемность на законодательном уровне.

Социум изнасилует тебя во всех мыслимых и немыслимых позициях.

И уже ТЫ станешь мемом. Тем более, если твоя причина аборт. Просто потому, что толпа обезумевших идиотов будет хором орать о твоей неполноценности, несостоятельности, разложении ${ }^{29}$.

Macierzyństwo traktowane jako „święte powołanie” stanowi najwyższą wartość tylko wtedy, gdy kobieta jest w heteroseksualnym związku (najlepiej zalegalizowanym) ${ }^{30}$. W ten sposób zinstytucjonalizowane macierzyństwo wartościuje kobiety: z jednej strony, deprecjonuje te, które nie mogą lub nie chcą mieć dzieci, z dru-

${ }^{29}$ Г. Бронникова, Глина, tekst sztuki dostępny na stronie festiwalu „Lubimowka”: https://lubimovka.ru/lyubimovka-god/622-short-list-2019 (24.08.2020).

${ }^{30}$ Zob. np. A. Rich, Zrodzone z kobiety. Macierzyństwo jako doświadczenie i instytucja, przeł. J. Mizielińska, Wydawnictwo Sic!, Warszawa 2000; Z. Gawlina, Macierzyństwo jako wartość w kontekście przemian społecznych, „Roczniki Socjologii Rodziny" 2003, t. 15, s. 33-45. 
giej, dzieli posiadanie potomstwa na „legalne” lub „nielegalne”, jak je określa Agnieszka Gajewska w swojej książce Hasło: feminizm ${ }^{31}$. Choć obecnie ciąże pozamałżeńskie nie są stygmatyzowane tak jak w poprzednich epokach, to nadal samotne macierzyństwo zostaje spychane na margines życia publicznego - niby akceptowane, a jednocześnie traktowane jako przeszkoda w nawiązaniu kolejnej relacji damsko-męskiej, co pokazuje Katia Swierdłowa w sztuce Childfree (Чайлдфри, 2018) ${ }^{32}$. Autorka przedstawia historię trzech przyjaciółek, z których każda na swój sposób radzi sobie z (nie) byciem matką - Jana próbuje pogodzić wychowywanie dziecka z karierą pianistki, Sasza zachodzi w nieplanową ciążę, a Regina jest zadeklarowaną członkinią ruchu childfree. Wraz z rozwojem wydarzeń okazuje się, że stosunek bohaterek do macierzyństwa nie wynika tylko $\mathrm{z}$ wewnętrznego przekonania, ale jest rodzajem kompromisu pomiędzy własnymi pragnieniami a oczekiwaniami otoczenia (np. niechęć Reginy do posiadania dzieci związana jest z nieprzepracowaną traumą po aborcji, której dokonała jako młoda dziewczyna).

Jeszcze inną odsłonę „nielegalnego” macierzyństwa prezentuje Natalia Milantjewa, która w utworze Dziecko dla Oli (Ребенок для Оли, 2016) dotyka kwestii macierzyństwa w relacjach nienormatywnych. Trudną sytuację dziecka pary lesbijek dodatkowo komplikuje fakt, że zajść w ciążę może tylko Żenia, która nigdy nie chciała być matką, a swoją orientację ukrywa przed rodzicami. Kiedy związek kobiet się rozpada, ciąża staje się dla Żeni przekleństwem. „Если вы не любите друг друга - зачем вы рожаете детей?!”зз — wykrzykuje bohaterka Jeleny Isajewej, wspomnianej już drama-

\footnotetext{
${ }^{31}$ A. Gajewska, Hasło: feminizm, Wydawnictwo Poznańskie, Poznań 2008, s. 234-236.

${ }^{32}$ К. Свердлова, Чайлдфри, tekst sztuki dostępny na stronie festiwalu „Remarka”, https://remarka-drama.ru/texts/plays_br2019/ (24.08.2020).

${ }^{33}$ Е. Исаева, Первый мужчина, „Новый мир” 2003, nr 11, https://magazines. gorky.media/novyi_mi/2003/11/pervyj-muzhchina.html (24.08.2020). Isajewa w swojej twórczości również podejmowała próby analizy trudnych stosunków rodzinnych, a w sztuce Pierwszy mężczyzna rozpatrywała relacje na linii córkaojciec.
} 
topisarki starszego pokolenia. Słowa te dobrze rezonują z opisanymi sztukami. Wszechobecny brak miłości - między partnerami, rodzicami i dziećmi, a także miłości i akceptacji siebie, swojej tożsamości czy orientacji - staje się przyczyną większości nieszczęść bohaterów sztuk młodych dramatopisarek.

Próby odnalezienia kobiecego "ja” podejmowane są także na płaszczyźnie seksualności i cielesności. Ciało kobiece jest zdecydowanie bardziej tabuizowane niż męskie, odnosi się do niego również więcej cech ambiwalentnych. Kobiety wciąż są oceniane za swoje podejście do seksu, co udowadnia sztuka Aliony Iwaniuszenko Skóra (Шкypa, 2018). „В тексте показаны [...] два пути для молодой девушки - либо 'шлюхи', либо девственницы” - konstatuje krytyczka teatralna Anastasija Wasiliewicz. Każda $\mathrm{z}$ dwóch zaprezentowanych dróg wiąże się z chęcią zdobycia męskiego uznania: w jednym wariancie swojego życia Jana, chcąc zyskać akceptację kolegów, nie protestuje, gdy ci wykorzystują ją seksualnie, w drugim - decyduje się na zachowanie czystości aż do ślubu, gdyż jej chłopak uważa, że tylko dziewica jest godna zostać jego żoną.

Inną wariację odwiecznej dychotomii między Jawnogrzesznicą a Piękną Damą, kobietą upadłą, femme fatale a nieskalaną grzechem namiętności żoną i matką przedstawia sztuka Iriny Waśkowskiej Wizyta (Buзum, 2017) ${ }^{35}$. Utwór ze względu na poetycki charakter i fragmentaryczną strukturę nazwany został „sztuką-płaczem”, „sztuką-poematem”36. Jest to tekst bez wyraźnie zarysowanych postaci, stanowiący potok myśli i wspomnień z licznymi odniesieniami do cielesności, seksualnych doświadczeń z dzieciństwa, młodo-

\footnotetext{
${ }^{34}$ A. Василевич, Женщины в современной драматургии, https://womenplatform.net/inspiration-and-development/zhenshhiny-v-sovremennoj-dramaturgii/ (24.08.2020).

${ }^{35}$ Sztuka została przetłumaczona na język polski i opublikowana w czasopiśmie „Dialog”. Zob. I. Waśkowska, Wizyta, przeł. A.L. Piotrowska, „Dialog” 2018, nr 3, s. 140-152.

${ }^{36}$ Zob. strona festiwalu „Lubimowka”, opis sztuki Wizyta przygotowany przez Wierę Sierdieczną, https://lubimovka.ru/lyubimovka-god/382-short-list-2017 (24.08.2020).
} 
ści i dorosłości, i prezentujący refleksję autorki nad granicą między dopuszczalnym i dobrowolnie eksperymentalnym w seksualności a molestowaniem i wykorzystaniem ${ }^{37}$.

Sprzeciw wobec negatywnego postrzegania kobiecego ciała wyraża Olga Szyliajewa w sztuce $28 d n i$ (28 днеŭ, 2018), której struktura formalna odpowiada fazom kobiecego cyklu. Dramatopisarka próbuje walczyć z postrzeganiem żeńskiego ciała jako niestabilnego, traktowanego tak m.in. ze względu na zmiany, jakie zachodzą $\mathrm{w}$ psychice i ciele kobiety podczas menstruacji ${ }^{38}$. Szyliajewa włącza w strefę widzialnego jedno z bardziej intymnych doświadczeń (fizjologicznie i emocjonalnie). Szukając odpowiedzi na pytania o istotę kobiecości, stawia tezę, że być może właśnie ta emocjonalność, impulsywność, tkliwość, wrażliwość, które są udziałem kobiet w określonych fazach cyklu, stanowią jej sedno:

\author{
Почему мы хотим \\ избавиться от ПМС? \\ Чтобы быть удобными? \\ [...] \\ Мы считаем, что \\ в ПМС мы ненормальные. \\ А может, наоборот? \\ В остальное время \\ мы - неадекватные? ${ }^{39}$
}

Rozmyślania nad funkcjonowaniem kobiecego organizmu Szyliajewa rozszerza o refleksję nad pozycją kobiety w świecie, pokazując, w jaki sposób mizoginistyczne społeczeństwo przyjmuje za naturalne kobiece cierpienie oraz zmusza ją do uległości. Cielesność, seksualność, zmiany hormonów zostają wykorzystane przeciwko kobietom. Bohaterka utworu od swojego przemocowego partnera słyszy: „Эти шрамы ты / сама себе сделала / моими руками” і socjalizowana do uznania swojej niższości,

\footnotetext{
${ }^{37}$ П. Руднев, Драма памяти ..., s. 443-444.

${ }^{38}$ Zob. J.M. Bardwick, E. Douvan, Ambiwalencja: socjalizowanie kobiet..., s. 170.

${ }^{39}$ О. Шиляева, 28 днец̆, tekst sztuki dostępny jest na stronie festiwalu „Lubimowka”: https://lubimovka.ru/istoriya/42-2018/516-short-list-2018 (24.08.2020).
} 
pyta siebie: „ОНА: / Он - агрессивный, / или я слишком / чувствительная?" 40 .

Pragnienie ucieczki od naprzykrzania się, molestowania i przemocy ze strony mężczyzn bywa powodem nienawiści do własnego ciała, co staje się udziałem bohaterki sztuki Jekateriny Czekatowskiej Mastektomia (Мастектомия, 2017-2018) - piersi, które obcy mężczyźni komentują, a często również dotykają wbrew jej woli, uznaje za źródło opresji i aby uniknąć nadużyć ze strony mężczyzn, decyduje się na mastektomię.

Чувствую себя прекрасно [...] пропал страх. Вот этот страх уязвимости, постоянная боязнь, что тебя в любой момент могут унизить, оскорбить, продемонстрировать свою власть, схватив тебя за грудь. Потому что груди нет! А нет груди - нет и инструмента для унижения"

- opisuje swoje uczucia po zabiegu. Z kolei bohaterka dramatu Natalii Błok Obchodzi mnie wszelkie g... (Меня волнует вся $x^{\star *}$, 2017) problem ze swoją kobiecością postanawia rozwiązać bardziej definitywnie — zgłasza się na operację zmiany płci. Doświadczenia agresji, molestowania, mizoginii, stereotypizacji ról społecznych czy braku akceptacji dla odmienności sprawiają, że załamana bohaterka wykrzykuje:

Я не псих. Я просто не могу быть больше женщиной. Это невыносимо. Вот вы когда-то испытывали страх, что вы беременны? А, что вас изнасилуют если вы среди мужчин находитесь? А, вам говорили, что вы тупой потому, что вы мужик? Я не хочу быть женщиной в этой стране. В этом мире вообще ${ }^{41}$.

Zaprezentowane przykłady stanowią — mimo że najbardziej komentowaną i zauważaną — zaledwie część rozważań na temat bycia kobietą we współczesnym świecie, poruszanych w twórczości najmłodszych rosyjskich dramatopisarek. Wybór utworów jest subiektywny, choć w znacznym stopniu opiera się na tych sztukach, które

\footnotetext{
${ }^{40}$ Tamże.

${ }^{41}$ Н. Блок, Меня волнует вся $x^{* *}$ ня, tekst sztuki dostępny jest na stronie festiwalu „Lubimowka”: https://lubimovka.ru/lyubimovka-god/382-shortlist-2017 (24.08.2020).
} 
zostały wyróżnione przez krytykę, widzów i czytelników. Autorki zdają sobie sprawę, że tożsamość ich bohaterek nie sprowadza się wyłącznie do płci biologicznej czy kulturowej, ale jest kształtowana również przez rasę, klasę społeczną, wykształcenie czy stan zdrowia, dlatego relacje władzy występują w wielu wymiarach. Wśród najnowszych utworów napisanych przez kobiety odnajdziemy więc także teksty będące reakcją na wydarzenia z pierwszych stron gazet (Zarema Zaudinowa, Jekaterina Kosariewskaja, Aleksiej Polichowicz Tortury / Пьıткu, 2018) czy poruszające problem niepełnosprawności (Polina Sinewa Obcy głos / Чужой голос, 2017), osób z chorobami psychicznymi (Masza Gawriłowa Płonę / Я горю, 2018) i imigrantów (Jekaterina Trojepolskaja, Aleksandr Rodionow Projekt „Swan” / Проект „Сван”, 2013).

Jak podkreślała Toril Moi w rozmowie z Małgorzatą Walicką-Hueckel, „[n]ie ma takiego doświadczenia, które byłoby przeżywane przez wszystkie kobiety w identyczny sposób” ${ }^{32}$, i tę różnorodność pokazują młode rosyjskojęzyczne dramatopisarki. Uwidaczniają wpływ doświadczeń i traum z dzieciństwa, relacji z rodzicami, oddziaływania (zwykle negatywnego) grup rówieśniczych czy środowisk społecznych na poczucie świadomości siebie. Kobiecy i mniejszościowy wielogłos rozszerza przestrzenie widzialnego, uwrażliwia na drugiego człowieka, sprawiając, że coraz rzadziej postrzegany jest jako Inny lub Obcy.

\section{REFERENCES}

Antologia współczesnego dramatu rosyjskiego. Vol. 7: Szkoła uralska. Ed. Moskwin, Andriej. Warszawa: SOWA, 2017.

Bardwick, Judith M., Douvan, Elizabeth. "Ambiwalencja: socjalizowanie kobiet.” Nikt nie rodzi się kobietą. Ed. and transl. Hołówka, Teresa. 165-186. Warszawa: Czytelnik, 1982.

Bednarek, Joanna. Linie kobiecości. Jak różnica płciowa przekształciła literaturę i filozofię. Warszawa: Narodowe Centrum Kultury-Fundacja na rzecz Myślenia im. Barbary Skargi, 2015.

Blok, Natal'ya. Menya volnuyet vsya $k h^{* *}$ yya. https://lubimovka.ru/lyubimovkagod/382-short-list-2017. Accessed 24 Aug. 2020 [Блок, Наталья. Меня

\footnotetext{
${ }^{42}$ Feminizm jest polityczny. Z Toril Moi rozmawia Małgorzata Walicka-Hueckel, „Teksty Drugie” 1993, nr 4-5-6, s. 108.
} 
волнует вся $x^{* *}$ ня. https://lubimovka.ru/lyubimovka-god/382-short-list-2017. Дата обращения: 24 августа 2020].

Bronnikova, Yekaterina. Glina. https://lubimovka.ru/lyubimovka-god/622-shortlist-2019. Accessed 24 Aug. 2020 [Бронникова, Екатерина. Глина. https:// lubimovka.ru/lyubimovka-god/622-short-list-2019. Дата обращения: 24 августа 2020].

"Feminizm jest polityczny. Z Toril Moi rozmawia Małgorzata Walicka-Hueckel." Teksty Drugie, no. 4-5-6, 1993: 97-114.

Frolova, Nadezhda. "V ogromnom kolichestve p'yes - voyna." https://lubimovka.ru/blog/396-v-ogromnom-kolichestve-pes-vojna. Accessed 24 Aug. 2020 [Фролова, Надежда. "В огромном количестве пьес - война." https://ubimovka.ru/blog/396-v-ogromnom-kolichestve-pes-vojna. Дата обращения: 24 августа 2020].

Gajewska, Agnieszka. Hasło: feminizm. Poznań: Wydawnictwo Poznańskie, 2008.

Gawlina, Zofia. "Macierzyństwo jako wartość w kontekście przemian społecznych.” Roczniki Socjologii Rodziny, vol. 15, 2003: 33-45.

Isayeva, Yelena. "Pervyy muzhchina." Novyy mir, no. 11, 2003, https://magazines. gorky.media/novyi_mi/2003/11/pervyj-muzhchina.html. Accessed 24 Aug. 2020 [Исаева, Елена. “Первый мужчина.” Новый мир, № 11, 2003, https:// magazines.gorky.media/novyi_mi/2003/11/pervyj-muzhchina.html. Дата обращения: 24 августа 2020].

Israilova, Marina, Dunayeva, Aleksandra. "Chetyre versii feministskogo iskusstva iz Peterburga." Teatr, no. 38, 2019, http://oteatre.info/chetyre-versiifeministskogo-iskusstva-iz-peterburga/. Accessed 24 Aug. 2020 [Исраилова, Марина, Дунаева, Александра. "Четыре версии феминистского искусства из Петербурга.” Театр, № 38, 2019, http://oteatre.info/chetyreversii-feministskogo-iskusstva-iz-peterburga/. Дата обращения: 24 августа 2020].

Karpova, Tat'yana N. "Gendernyy faktor v dramaturgicheskom tekste." Vestnik VGU. Seriya: Filologiya. Zhurnalistika, no. 3, 2016: 46-48 [Карпова, Татьяна Н. “Гендерный фактор в драматургическом тексте.” Вестник ВГУ. Серия: Филология. Журналистика, № 3, 2016: 46-48].

Karpova, Tat'yana N. "K voprosu o dinamike tvorcheskoy aktivnosti zhenshchindramaturgov: prichiny i faktory." Istoricheskiye, filosofskiye, politicheskiye $i$ yuridicheskiye nauki, kul'turologiya $i$ iskusstvovedeniye. Voprosy teorii i praktiki, no. 5 (43), 2014: 97-101 [Карпова, Татьяна Н. “К вопросу о динамике творческой активности женщин-драматургов: причины и факторы." Исторические, философские, политические и юридические науки, культурология и искусствоведение. Вопросы теории и практики, № 5 (43), 2014: 97-101].

Karpova, Tat'yana N. "Zhenskaya dramaturgiya perioda zastoya v aspekte gendernogo dialoga." Istoricheskiye, filosofskiye, politicheskiye $i$ yuridicheskiye nauki, kul'turologiya $i$ iskusstvovedeniye. Voprosy teorii i praktiki, no. 5 (67), 2016: 99-103 [Карпова, Татьяна Н. “Женская драматургия периода застоя в аспекте гендерного диалога.” Исторические, философские, политиче- 
ские и юридические науки, культурология и искусствоведение. Вопросы теории и практики, № 5 (67), 2016: 99-103].

Kocherina, Svetlana V., Mekayeva, Yuliya Y. Sovremennaya dramaturgiya: sostoyaniye, tendentsii, perspektivy. Sotsiologicheskoye issledovaniye. Moskva: Akademika, 2008 [Кочерина, Светлана В., Мекаева, Юлия Ю. Современная драматургия: состояние, тендениии, перспективы. Социологическое исследование. Москва: Академика, 2008].

Mamadnazarbekova, Kamila. "Novyy feminizm po-frantsuzski: za vashu i nashu svobodu." Teatr no. 38, 2019, http://oteatre.info/novyj-feminizm-po-frantsuzski/. Accessed 24 Aug. 2020 [Мамадназарбекова, Камила. "Новый феминизм по-французски: за вашу и нашу свободу.” Театр, № 38, 2019, http://oteatre.info/novyj-feminizm-po-frantsuzski/. Дата обращения: 24 августа 2020].

Markowski, Michał Paweł. "Feminizm.” Teorie literatury XX wieku. Ed. Burzyńska, Anna, Markowski, Michał Paweł. 391-402. Kraków: Znak, 2006.

Matviyenko, Kristina. “Novaya drama': pobeda bez triumfa." Iskusstvo kino, no. 3, 2014, http://kinoart.ru/archive/2014/03/novaya-drama-pobeda-bez-triumfa. Accessed 24 Aug. 2020 [Матвиенко, Кристина. “Новая драма’: победа без триумфа.” Искусство кино, № 3, 2014, http://kinoart.ru/archive/2014/03/ novaya-drama-pobeda-bez-triumfa. Дата обращения: 24 августа 2020].

Mazurek, Halina. Róża i Płaszcz. Teatr Mariny Cwietajewej. Katowice: WW Oficyna Wydawnicza, 2009.

Mikhaylova, Mariya V. “Baby s p'yesami...' v epokhu modern (predisloviye)." Zhenskaya dramaturgiya Serebryanogo veka. Ed. Mikhaylova, Mariya V. 5-64. Sankt-Peterburg: Giperion, 2009 [Михайлова, Мария В. “'Бабы с пьесами...’ в эпоху modern (предисловие)." Женская драматургия Серебряного века. Сост. Михайлова, Мария В. 5-64. Санкт-Петербург: Гиперион, 2009].

Piłat, Walenty. "Współczesna 'kobieca' dramaturgia radziecka.” Język Rosyjski, no. 5, 1989: 259-264.

Rich, Adrienne. Zrodzone z kobiety. Macierzyństwo jako doświadczenie i instytucja. Transl. Mizielińska, Joanna. Warszawa: Wydawnictwo Sic!, 2000.

Rowieńska, Tatiana. "Historia prozy kobiecej w epoce transformacji, czyli 'oczy szeroko zamknięte’ rosyjskiego feminizmu.” Transl. Kuźmina, Irina. Literatury słowiańskie po roku 1989. Nowe zjawiska, tendencje, perspektywy. Vol. 2: Feminizm. Ed. Kraskowska, Ewa. 84-94. Warszawa: Kolor Plus, 2005.

Rudnev, Pavel. Drama pamyati. Ocherki istorii rossiyskoy dramaturgii. 1950-2010ye. Moskva: Novoye literaturnoye obozreniye, 2018 [Руднев, Павел. Драма памяти. Очерки истории российской драматургии. 1950-2010-е. Москва: Новое литературное обозрение, 2018].

Shilyayeva, Ol'ga. 28 dney. https://lubimovka.ru/istoriya/42-2018/516-shortlist-2018. Accessed 24 August 2020 [Шиляева, Ольга. 28 дней. https:// lubimovka.ru/istoriya/42-2018/516-short-list-2018. Дата обращения: 24 августа 2020].

Slyusarenko, Dar'ya. Sem'yu vosem'. https://lubimovka.ru/lyubimovka-god/622short-list-2019. Accessed 24 Aug. 2020 [Слюсаренко, Дарья. Семью 
восемь. https://lubimovka.ru/lyubimovka-god/622-short-list-2019. Дата обращения: 24 августа 2020].

Sverdlova, Katya. Chayldfri. https://remarka-drama.ru/texts/plays_br2019/. Accessed 24 Aug. 2020 [Свердлова, Катя. Чайлдфри. https://remarka-drama. ru/texts/plays_br2019/. Дата обращения: 24 августа 2020].

Tyczko, Krzysztof. "Wolność i tragizm w twórczości Asi Wołoszyny." Maski wolności w dramacie i teatrze XX i XXI wieku. Ed. Mięsowska, Lidia, CharkoKlekot, Paulina, Tyka, Anna. 295-313. Katowice: "Śląsk," 2019.

Vasilevich, Anastasiya. "Zhenshchiny v sovremennoy dramaturgii." https://womenplatform.net/inspiration-and-development/zhenshhiny-v-sovremennojdramaturgii/. Accessed 24 Aug. 2020 [Василевич, Анастасия. “Женщины в современной драматургии.” https://womenplatform.net/inspiration-anddevelopment/zhenshhiny-v-sovremennoj-dramaturgii/. Дата обращения: 24 августа 2020].

Waśkowska, Irina. "Wizyta." Transl. Piotrowska, Agnieszka Lubomira. Dialog, no. 3, 2018: 160-185.

Wołoszyna, Asia. Mama. Transl. Tyczko, Krzysztof. Dialog, no. 3, 2018: 160-185.

Wójcik, Anna. "Geopolityka namiętności. Rozmowa z Jacquesem [!] Rancièrem." https://publica.pl/teksty/geopolityka-namietnosci-rozmowa-z-jacquesemrancierem-51329.html. Accessed 24 Aug. 2020.

Zaytseva, Natal'ya. "Rossiyskaya dramaturgiya: nastroyka optiki." Teatr, no. 38, 2019, http://oteatre.info/nastrojka-optiki-o-feministskom-povorote-v-rossijskoj-dramaturgii/. Accessed 24 Aug. 2020 [Зайцева, Наталья. “Российская драматургия: настройка оптики.” Театр, № 38, 2019, http://oteatre.info/ nastrojka-optiki-o-feministskom-povorote-v-rossijskoj-dramaturgii/. Дата обращения: 24 августа 2020].

“'Zhenskiy mir stal pristal'nym ob”yektom issledovaniya'. Uchastnitsy 'Lyubimovki' o gendere i tom, pochemu zhenshchin v dramaturgii stanovitsya vse bolshe." https://www.kommersant.ru/doc/4080460. Accessed 24 Aug. 2020 [““Женский мир стал пристальным объектом исследования'. Участницы 'Любимовки' о гендере и том, почему женщин в драматургии становится все больше.” https://www.kommersant.ru/doc/4080460. Дата обращения: 24 августа 2020]. 